\title{
Hungary: a European hotspot of non-native crayfish biodiversity
}

\author{
András Weiperth ${ }^{1}$, Martin Bláha ${ }^{2}$, Bettina Szajbert ${ }^{3}$, Richárd Seprős ${ }^{4}$, Zsombor Bányai ${ }^{5}$, Jiří Patoka ${ }^{6}$ \\ and Antonín Kouba ${ }^{2, *}$ \\ ${ }^{1}$ Szent István University, Faculty of Agriculture and Environmental Sciences, Institute for Natural Resources Conservation, Department \\ of Aquaculture, Páter Károly utca 1, 2100 Gödöllö, Hungary \\ ${ }^{2}$ University of South Bohemia in České Budějovice, Faculty of Fisheries and Protection of Waters, South Bohemian Research Center of \\ Aquaculture and Biodiversity of Hydrocenoses, Zátiší 728/II, 38925 Vodňany, Czech Republic \\ ${ }^{3}$ ELTE Eötvös Loránd Univerity, Department of Systematic Zoology and Ecology, Behavioural Ecology Group, Pázmány Péter sétány \\ 1/C, 1117 Budapest, Hungary \\ ${ }^{4}$ Herman Ottó Institute Nonprofit Ltd., Park utca 2, 1223 Budapest, Hungary \\ ${ }^{5}$ ELKH Centre for Ecological Research, Danube Research Institute, Karolina út 29, 1113 Budapest, Hungary \\ ${ }^{6}$ Czech University of Life Sciences Prague, Faculty of Agrobiology, Food and Natural Resources, Department of Zoology and Fisheries, \\ Kamýcká 129, 16500 Prague-Suchdol, Czech Republic
}

Received: 25 August 2020 / Accepted: 2 November 2020

\begin{abstract}
There is a long history of crayfish introductions in Europe and numbers keep increasing. In Hungary, spiny-cheek crayfish Faxonius limosus, signal crayfish Pacifastacus leniusculus, red swamp crayfish Procambarus clarkii, marbled crayfish P. virginalis and Mexican dwarf crayfish Cambarellus patzcuarensis have become established. Here we report on monitoring at two localities with novel crayfish assemblages closely linked to releases associated with the pet trade. Florida crayfish Procambarus alleni were recorded from the Gombás brook near Vác living in syntopy with the established spiny-cheek crayfish. Dozens of Florida crayfish individuals including egg-carrying females have been detected. The short lifespan of this species and its documented presence including two overwintering in at least two years suggests possible establishment. However, the lack of juvenile records calls for further monitoring as longterm propagule pressure cannot be ruled out. We also identified a single marbled crayfish in the Danube floodplain at the end of the monitoring campaign. The second locality (Városliget thermal pond in Budapest) harbours an even more diverse crayfish assemblage. Here, we identified numerous red swamp and marbled crayfish in syntopy with dozens of monitored redclaws Cherax quadricarinatus and seven individuals of New Guinean Cherax species - C. holthuisi, C. snowden, as well as two scientifically undescribed species. These findings clearly indicate the attractiveness of urban and, especially, thermal waters for the release of even expensive aquatic pets and highlight the hitherto poorly known biodiversity of New Guinean crayfish species.
\end{abstract}

Keywords: pet trade / biological invasion / animal release / invasive species / thermal water

Résumé - Hongrie : un point chaud européen de la biodiversité des écrevisses non indigènes. Les introductions d'écrevisse en Europe est une longue histoire et leur nombre ne cesse d'augmenter. En Hongrie, l'écrevisse américaine Faxonius limosus, l'écrevisse signal Pacifastacus leniusculus, l'écrevisse rouge de Louisiane Procambarus clarkii, l'écrevisse marbrée $P$. virginalis et l'écrevisse naine mexicaine Cambarellus patzcuarensis se sont établies. Nous présentons ici un rapport sur la surveillance à long terme dans deux localités où des assemblages d'écrevisses nouvelles sont étroitement liés aux lâchers associés au commerce des animaux de compagnie. L'écrevisse bleue Procambarus alleni a été observée dans le ruisseau de Gombás, près de Vác, vivant en syntopie avec l'écrevisse américaine établie. Des dizaines d'individus d'écrevisses de Louisiane, y compris des femelles porteuses d'œufs, ont été détectées. La courte durée de vie de cette espèce et sa présence documentée, y compris deux hibernations en au moins deux ans, suggèrent une possible implantation. Toutefois, l'absence de données sur les juvéniles exige une surveillance plus poussée, car on ne peut exclure la possibilité d'une pression de propagation à long terme. Nous avons également identifié une seule écrevisse marbrée dans la plaine d'inondation du Danube à la fin de la mission de

\footnotetext{
${ }^{*}$ Corresponding author: akouba@frov.jcu.cz
} 
surveillance. La deuxième localité (l'étang thermal de Városliget à Budapest) abrite un assemblage d'écrevisses encore plus diversifié. Ici, nous avons identifié de nombreuses écrevisses rouges de Louisiane et marbrées en syntopie avec des dizaines de Cherax quadricarinatus et sept individus d'espèces de Cherax de Nouvelle-Guinée - C. holthuisi, $C$. snowden, ainsi que deux espèces non décrites scientifiquement. Ces résultats indiquent clairement l'attrait des eaux urbaines et, surtout, des eaux thermales pour le lâcher d'animaux aquatiques, même coûteux, et mettent en évidence la biodiversité jusqu'ici mal connue des espèces d'écrevisses de Nouvelle-Guinée.

Mots-clés : commerce d'animaux de compagnie / invasion biologique / lâcher d'animaux / espèces envahissantes / eaux thermales

\section{Introduction}

Biological invasions have a negative impact on native biodiversity and ecosystem functioning (Simberloff et al., 2013). Rates of biological invasions are continuously accelerating worldwide among both taxa and regions (Seebens et al., 2017). Crayfish, ecologically important animals and freshwater ecosystem engineers (Kouba et al., 2016; Momot, 1995), are an integral part of these processes (Holdich et al., 2009; Twardochleb et al., 2013). Several crayfish species are known to be highly invasive (Gherardi and Acquistapace, 2007; Lodge et al., 2000) and many native crayfish species may be directly or indirectly threatened by the appearance of their non-native counterparts (Crandall and Buhay, 2008; Richman et al., 2015; Taylor et al., 2019).

The total number of crayfish species native to Europe is relatively low (Holdich et al., 2009; Kouba et al., 2014). Nevertheless, species diversity in the genus Austropotamobius is just beginning to be fully appreciated (Jelić et al., 2016; Klobučar et al., 2013; Lovrenčić et al., 2020; Pârvulescu et al., 2019), which has among others resulted in the recently discovered idle crayfish A. bihariensis (Pârvulescu, 2019). The greatest degree of species diversity is expected to occur in Eastern Europe, essentially related to the genus Pontastacus. However, this question has never been investigated thoroughly and clear evidence for this hypothetical species diversity (Crandall and De Grave, 2017) remains lacking (Bláha et al., 2020; Bláha et al., 2017; Maguire et al., 2014).

In Europe, the first outbreaks of the so-called crayfish plague appeared in 1860 and soon affected the then numerous stocks of native crayfish species. The resulting declines stimulated interest in stocking with alternative crayfish species that were resistant to the causative agent of the disease, an oomycete Aphanomyces astaci (Svoboda et al., 2017). Initially, three species originating from North America (spiny-cheek crayfish Faxonius limosus in 1890, signal crayfish Pacifastacus leniusculus in 1959, and red swamp crayfish Procambarus clarkii in 1973) were introduced for use in fisheries and/or aquaculture (Holdich et al., 2009). However, it became clear that the crayfish species native to North America are chronic carriers of this pathogen. As their ranges have expanded, these non-native species have spread this parasite, to which the crayfish species from other regions are usually highly susceptible (Svoboda et al., 2017; Ungureanu et al., 2020). The above-mentioned non-native crayfish species have become widespread in Europe (Kouba et al., 2014) and are now classified as invasive species of European Union concern (EU, 2014, 2016) as they pose a serious threat not only to native crayfish but also to entire freshwater ecosystems.

Unfortunately, the number of non-native crayfish species has continued to increase, frequently due to both intentional and non-intentional releases of originally pet-traded individuals or their offspring that are kept for ornamental purposes (Patoka et al., 2016; Weiperth et al., 2019). In recent years, various monitoring programs including astacological surveys have yielded valuable distributional data on both native and non-native crayfish species in Hungary (Gál et al., 2018; Ludányi et al., 2016; Seprős et al., 2018), including information regarding multiple releases of redclaw Cherax quadricarinatus in the wild (Weiperth et al., 2019) and the confirmed establishment of marbled crayfish Procambarus virginalis and red swamp crayfish (Gál et al., 2018; Kovács et al., 2015; Lőkkös et al., 2016; Weiperth et al., 2015; Weiperth et al., 2020). Additionally, the Mexican dwarf crayfish Cambarellus patzcuarensis was discovered in Budapest in 2017 (Weiperth et al., 2017). Unfortunately, this increase in non-native species shows no signs of abating and further species are still appearing. As biomonitoring work continues in Hungary, interesting new discoveries are occurring. Here we report the results of long-term monitoring at two localities in Hungary that are home to three and seven co-occurring crayfish species.

\section{Materials and methods}

\subsection{Gombás brook}

Under the auspices of project NVKP_16-1-2016-0003 (National Research, Development and Innovation Office), the Gombás brook near Vác, Hungary, was monitored monthly in 2017-2018 using the EU Water Framework Directive (European Commission, 2009) and Hungarian Biodiversity Monitoring System (www.termeszetvedelem.hu) methodologies to investigate fish populations. During this survey, a wellestablished population of the spiny-cheek crayfish was regularly observed. On the last sampling day on 31 August 2018 two individuals of a new crayfish species, later identified as the Florida crayfish Procambarus alleni, were caught by electrofishing (DEKA 3000 Lord, Hans Grassl IG 600). This encouraged the setting up of a regular, usually monthly-based, monitoring program focused on crayfish presence (Tab. 1). Five monitoring points were established and during each sampling event a baited crayfish trap made from PET bottles was placed at each point and left for 24 hours. This monitoring was accompanied by manual searching using hand-held nets 
Table 1. Gombás brook (near Vác, Hungary). The number of sampling point and the name of the locality with a description of the site and GPS coordinates are given.

\begin{tabular}{lll}
\hline No. & Locality & GPS \\
\hline 1 & Gombás brook (inflow from a rainwater water pipe and surrounding waters) & $47^{\circ} 46^{\prime} 8.57^{\prime \prime} \mathrm{N}$, \\
$19^{\circ} 8^{\prime} 17.31^{\prime \prime} \mathrm{E}$ & $47^{\circ} 46^{\prime} 8.09^{\prime \prime} \mathrm{N}$, \\
2 & Gombás brook (pedestrian footbridge) & $19^{\circ} 8^{\prime} 15.95^{\prime \prime} \mathrm{E}$ \\
4 & & $47^{\circ} 46^{\prime} 5.34^{\prime \prime} \mathrm{N}$, \\
$19^{\circ} 8^{\prime} 8.42^{\prime \prime} \mathrm{E}$ \\
4 & Gombás brook (corner of sports field) & $47^{\circ} 46^{\prime} 1.69^{\prime \prime} \mathrm{N}$, \\
4 & & $19^{\circ} 8^{\prime} 3.40^{\prime \prime} \mathrm{E}$ \\
5 & Gombás brook (Euvovelo six-bicycle bridge) & $47^{\circ} 45^{\prime} 55.32^{\prime \prime} \mathrm{N}$, \\
$19^{\circ} 8^{\prime} 4.97^{\prime \prime} \mathrm{E}$ & \\
\hline
\end{tabular}

Table 2. Gombás brook (near Vác, Hungary). Detailed characteristics of the locality and sampling points with the range of each parameter during the survey period (August 2018-July 2020).

\begin{tabular}{|c|c|c|c|c|c|}
\hline \multirow[t]{2}{*}{ Environmental parameters } & \multicolumn{5}{|c|}{ Sampling point } \\
\hline & 1 & 2 & 3 & 4 & 5 \\
\hline Water temperature $\left({ }^{\circ} \mathrm{C}\right)$ & $7.2-24.2$ & $4.9-26.5$ & $4.2-24.6$ & $4.0-24.8$ & $3.2-26.8$ \\
\hline Water depth $(\mathrm{cm})$ & $5-100$ & $10-60$ & $10-50$ & $10-50$ & $5-70$ \\
\hline Distance from the bank (m) & $0.1-1.5$ & $0.5-2.0$ & $0.5-2.0$ & $0.5-2.0$ & $0.5-5.0$ \\
\hline Water velocity $(\mathrm{m} / \mathrm{s})$ & $0-0.2$ & $0-0.2$ & $0-0.2$ & $0-0.2$ & $0-0.2$ \\
\hline Submerged vegetation (\%) & $0-10$ & 0 & $0-10$ & 0 & $0-10$ \\
\hline Emergent vegetation (\%) & $0-25$ & $0-15$ & $0-10$ & $0-10$ & $0-35$ \\
\hline Woody debris $(\%)$ & $0-15$ & $0-20$ & $0-15$ & $0-10$ & $0-30$ \\
\hline Shading tree cover $(\%)$ & $0-10$ & $10-30$ & $10-30$ & $5-20$ & $0-40$ \\
\hline Depth of sediment (m) & $0.3-0.8$ & $0.05-0.5$ & $0.1-0.6$ & $0.2-0.6$ & $0.2-0.5$ \\
\hline Type of bottom & Concrete, stone, organic sludge & Concrete, mud & Mud, stone & Clay, mud & Clay, mud \\
\hline
\end{tabular}

by two field workers, one on each shore. Sampling took place usually once a month from August 2018 to July 2020. Sampled crayfish were collected for species identification (see below) and sexing, and their carapace (CL) and total body (TL) were measured using calipers to the nearest $0.1 \mathrm{~mm}$. Females were checked for glair glands and attached eggs. Detailed characteristics of the localities and sampling points are given in Table 2.

\subsection{Városliget pond}

Városliget is one of the biggest thermal ponds in Budapest, Hungary, and is divided into three sections (Fig. 1). In general, the whole area has been heavily modified by human activity, although the lower section is still semi-natural. Inflow from the thermal spring located under the Széchényi thermal bath enters the upper section of the pond $\left(47^{\circ} 31^{\prime} 4.14^{\prime \prime} \mathrm{N}, 19^{\circ} 4^{\prime} 43.34^{\prime \prime} \mathrm{E}\right.$; sampling point 1, Fig. 1). A weir separates the middle and lower sections $\left(47^{\circ} 30^{\prime} 57.00^{\prime \prime} \mathrm{N}, 19^{\circ} 4^{\prime} 54.5^{\prime \prime} \mathrm{E}\right)$. After draining, cleaning, and refilling, the middle section is used as a public ice rink in winter (from the end of November to mid-March), during which time the thermal water from the upper section bypasses and flows directly into the River Danube. The outflow also flows directly into the River Danube $\left(47^{\circ} 31^{\prime} 0.115^{\prime \prime} \mathrm{N}\right.$, $19^{\circ} 4^{\prime} 43.044^{\prime \prime} \mathrm{E}$, close to sampling point 3 ). This locality was previously known to harbor both marbled and red swamp crayfish, with the marbled crayfish first appearing earlier (Weiperth et al., 2015). Since 2019, there have been occasional records of redclaws (Weiperth et al., 2020). An individual of another New Guinean Cherax species was first detected on 10 January 2019 in a crayfish trap at sampling point 4, close to a local restaurant (see Fig. 1). This initiated a regular monthlybased monitoring program focused on the presence of Cherax crayfish species. Five baited crayfish traps made from PET bottles were left for 24 hours at specific sites along the shores of the upper section every month in January 2019-July 2020. The greater water depth, the structure of the embankment, and the high conductivity of the water prevented electrofishing at this locality. Additionally, manual searching using hand-held nets was conducted in the middle and lower section at night for one hour by two people. The sampling of the middle section was discontinued during the ice-skating season (see above). The only exception was November 2019, when the middle section was drained and crayfish could be collected by hand in the shallow water. This explains why more crayfish were detected that month (see Results). The numerous red swamp and marbled crayfish were only categorized (females/males/ juveniles smaller ca. $25 \mathrm{~mm}$ of TL), while Cherax individuals (the prime target of this monitoring effort) were measured 

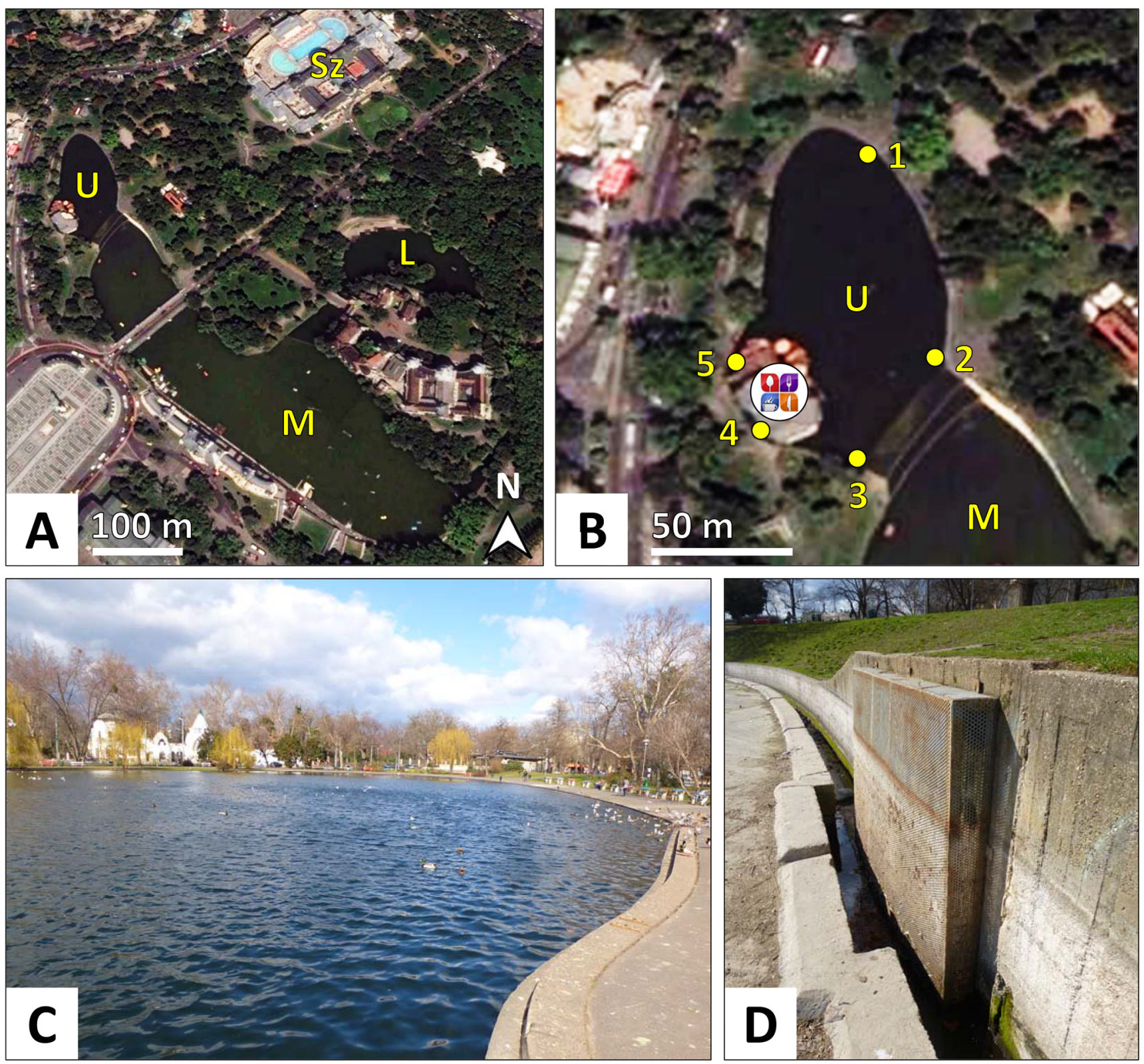

Fig. 1. (A) Three sections of the Városliget pond system in Budapest, Hungary; U: upper section, M: middle section, L: lower section, Sz: Széchényi thermal bath. (B) Detail of the upper section with sampling points indicated by numbers. The restaurant under which all Cherax individuals other than the redclaw were caught is located between sampling points 4 and 5. Maps taken from Google Earth. (C) The upper section of the thermal pond in early March 2020. (D) The iron grid on the outflow of the pond in January 2020. The stain on the grid and concrete wall indicates the water level in the middle section from the end of March until the end of October.

as indicated above. Detailed characteristics of the locality are given in Table 3.

\subsection{Species identification}

Samples from one Florida crayfish, one marbled crayfish (Gombás brook), and all Cherax specimens other than the redclaw (Városliget thermal pond) were molecularly analyzed. Genomic DNA extraction and PCR amplification were performed according to Bláha et al. (2016). Two mitochondrial genes, COI and 16S rRNA, were amplified with primers LCO1490 and HCO-2198 (Folmer et al., 1994), and 16S-1471 and
16S-1472 (Crandall and Fitzpatrick Jr, 1996), respectively. Only COI was amplified in the Florida crayfish and marbled crayfish specimens. Product purification and sequencing was performed by Macrogen Inc., South Korea. Obtained sequences were checked manually in GENEIOUS 8.0.5 (Kearse et al., 2012). The most similar sequences were located using standard nucleotide BLAST (https://blast.ncbi. nlm.nih.gov/) implemented in GENEIOUS.

The Bayesian implementation of the Poisson tree processes (PTP) model with non-ultrametric gene trees was performed using the bPTP web server (http://species.h-its.org/) for species delimitation (Zhang et al., 2013). The tree was 
Table 3. Városliget pond (Budapest, Hungary). Detailed characteristics of the site and sampling points, with the range of each parameter, during the survey period (August 2018-July 2020).

\begin{tabular}{llll}
\hline Environmental parameters & Upper section & Middle section & Lower section \\
\hline Water temperature $\left({ }^{\circ} \mathrm{C}\right)$ & $19.9-38.4$ & $5.3-38.2$ & $2.6-32.1$ \\
Water depth $(\mathrm{cm})$ & $135-150$ & $10-125$ & $0.05-110$ \\
Distance from the bank (m) & $0.1-0.5$ & $0.5-3$ & $0.1-0.5$ \\
Water velocity (m/s) & $0-0.1$ & 0 & 0 \\
Submerged vegetation (\%) & 0 & 0 & $0-0.02$ \\
Emergent vegetation (\%) & 0 & $0-0.01$ & 0 \\
Woody debris $(\%)$ & $<10$ & $<10$ & $<20$ \\
Shading tree cover $(\%)$ & $<15$ & $<10$ & $<30$ \\
Depth of sediment (m) & $0.10-0.45$ & 0.05 & $0.05-0.30$ \\
Type of bottom & concrete and mud ${ }^{1,2}$ & concrete and mud ${ }^{2}$ & concrete and mud \\
\hline
\end{tabular}

${ }^{1}$ Covered with filamentous algae during vegetation period.

${ }^{2}$ Leaves observed in the autumn and winter.

assigned as rooted and the outgroup was excluded from the analysis. Although for species delimitation, the standalone PTP model generally outperforms the general mixed Yule coalescent (GMYC) method (Fujisawa and Barraclough, 2013), both of these approaches were used. The nonultrametric tree was constructed in BEAST v2.5.1 (Drummond and Rambaut, 2007) under $\mathrm{TrN}+\mathrm{G}+\mathrm{I}$ model for COI dataset. The search was set to 50 million generations and was sampled every 5,000 generations, and the run was analyzed in TRACER (Rambaut et al., 2014) to check for chain convergence. The posterior distributions of the topologies generated during the analyzes were synthesized using maximum clade credibility (MCC) trees in TreeAnnotator 1.8.1 (Drummond and Rambaut, 2007).

\section{Results}

\subsection{Gombás brook}

In total, 130 crayfish were caught during the monitoring period (Tab. 4). The dominant species was the spiny-cheek crayfish (99 individuals; 67 females and 32 males) at all sampling points. Three out of five spiny-cheek crayfish females caught had glair glands in September 2018 and one out of five females was carrying eggs in October 2018. The female caught in June 2019 had the remains of eggshells. Three out of 11 females also had eggs in October 2019 (Tab. 4).

The generally blue coloration of the captured individuals (Fig. 2) suggested that this species was the Florida crayfish, which was subsequently confirmed by the COI gene barcoding (GenBank accession number COI: MT832311) that had a $100 \%$ match with the sequence of Florida crayfish mitochondrion (KT074363). In total, 31 Florida crayfish ( 25 females and 6 males) were detected in the two upper sampling points, with just one female at sampling point 3. A single Florida crayfish was seen being consumed by a grey heron (Ardea cinerea) close to sampling point 5 (B. Tóth, pers. obs., April 2020; not included in data). Three out of 13 females had glair glands in September 2018, and three out of six females had eggs a month later. These successfully hatched in a home aquarium at room temperature in January 2019. Florida crayfish were detected throughout the monitoring period, which suggests that it successfully overwintered in at least two years. Sampling in early autumn was the most productive, while cold periods resulted predictably in few crayfish. The spiny-cheek crayfish population seemed to be normally distributed in terms of body sizes; Florida crayfish were on average larger with two more abundant classes (50-70 and 90-100 mm TL; Fig. 3). Juveniles of the dominant spiny-cheek crayfish $(<25 \mathrm{~mm}$ TL) were regularly observed but were not counted. The smallest Florida crayfish was $42.2 \mathrm{~mm}$ TL (19.8 mm CL). Additionally, a single marbled crayfish was also detected at sampling point 5 at the end of monitoring campaign. COI gene barcoding (GenBank accession number COI: MT832312) revealed $100 \%$ similarity with several sequences of the marbled crayfish mitochondrion (HM358010, HM358011 - Martin et al., 2010; KT074364 Vogt et al., 2015).

\subsection{Városliget pond}

In total, 2165 crayfish belonging to seven species were caught during the monitoring period at Városliget (Tab. 5). Red swamp and marbled crayfish dominated (1020 and 1113 individuals, respectively) and were regularly sampled throughout the whole monitoring period. Juvenile red swamp crayfish represented one third (32\%) of all sampled individuals. Adults were dominated by males (68\%). Adult and juvenile marbled crayfish were present in similar numbers $(535$ and 578 , respectively).

Twenty-six ( 8 females and 18 males) redclaws were caught, with highest numbers recorded in the second half of 2019. Females and males ranged in size from 51.0 to 102.3 and 66.9 to $115.8 \mathrm{~mm} \mathrm{TL}$, respectively (corresponding to 22.2 42.0 and $26.8-48.3 \mathrm{~mm} \mathrm{CL}$ ). Neither glair glands, eggs, nor juveniles were detected.

A further five Cherax crayfish caught at the locality were not redclaws: all were trapped at sampling point 4 in the vicinity of a restaurant. The first individual (Fig. 4) noticed in January 2019 was a male measuring $38.1 \mathrm{~mm}$ CL (GenBank accession numbers COI: MT833298, 16SrRNA: MT833284). This individual was partly predated by the red swamp and marbled crayfish present in the exposed trap. Molecular 
A. Weiperth et al.: Knowl. Manag. Aquat. Ecosyst. 2020, 421, 43

Table 4. Gombás brook (near Vác, Hungary). The dates (month and year) and number of sampling occasions within a given month at five sampling points, with the number of captured individuals of females/males (when applicable) of the Florida crayfish Procambarus alleni and spiny-cheek crayfish Faxonius limosus. Note that a marbled crayfish P. virginalis individual was also caught at sampling point 5 in July 2020.

\begin{tabular}{|c|c|c|c|c|c|}
\hline \multirow[t]{2}{*}{ Date/number of samplings per month } & \multicolumn{5}{|c|}{ Sampling point } \\
\hline & 1 & 2 & 3 & 4 & 5 \\
\hline VIII. 2018/1 & $0 / 0 \& 2 / 0$ & $1 / 1 \& 2 / 0$ & $0 / 0 \& 1 / 1$ & - & $0 / 0 \& 0 / 1$ \\
\hline IX. $2018 / 4$ & $8 / 1 \& 0 / 0$ & $5 / 1 \& 0 / 0$ & $0 / 0 \& 1 / 2$ & $0 / 0 \& 3 / 1$ & $0 / 0 \& 1 / 0$ \\
\hline X. 2018/4 & $3 / 0 \& 0 / 0$ & $2 / 0 \& 1 / 3$ & $1 / 0 \& 1 / 2$ & $0 / 0 \& 2 / 0$ & $0 / 0 \& 1 / 0$ \\
\hline XI. 2018/1 & - & $0 / 0 \& 2 / 0$ & $0 / 0 \& 1 / 0$ & - & - \\
\hline XII. 2018/2 & $0 / 0 \& 1 / 0$ & $0 / 0 \& 1 / 0$ & - & - & - \\
\hline I. $2019 / 1$ & - & - & - & - & - \\
\hline II. $2019 / 1$ & - & - & - & - & - \\
\hline III. 2019/1 & $0 / 0 \& 1 / 0$ & - & - & - & - \\
\hline IV. $2019 / 2$ & $1 / 1 \& 0 / 0$ & - & $0 / 0 \& 0 / 1$ & $0 / 0 \& 1 / 0$ & - \\
\hline V. 2019/2 & $2 / 0 \& 0 / 0$ & $0 / 0 \& 1 / 0$ & - & - & - \\
\hline VI. 2019/2 & - & - & $0 / 0 \& 0 / 1$ & $0 / 0 \& 1 / 0$ & - \\
\hline VII. 2019/1 & - & $0 / 0 \& 1 / 0$ & $0 / 0 \& 1 / 0$ & $0 / 0 \& 1 / 1$ & - \\
\hline VIII. 2019/1 & - & $0 / 0 \& 1 / 0$ & $0 / 0 \& 1 / 1$ & $0 / 0 \& 0 / 1$ & - \\
\hline IX. 2019/4 & $1 / 0 \& 2 / 3$ & $0 / 0 \& 2 / 2$ & $0 / 0 \& 2 / 0$ & - & - \\
\hline X. 2019/4 & - & $0 / 0 \& 8 / 2$ & $0 / 0 \& 3 / 1$ & - & - \\
\hline XI. 2019/2 & - & $0 / 0 \& 2 / 1$ & $0 / 0 \& 1 / 0$ & - & - \\
\hline XII. 2019/1 & - & - & - & - & - \\
\hline I. $2020 / 1$ & - & - & - & - & - \\
\hline II. 2020/1 & $0 / 0 \& 0 / 1$ & $0 / 0 \& 0 / 1$ & - & - & - \\
\hline III. 2020/1 & - & $0 / 0 \& 1 / 0$ & - & - & - \\
\hline IV. $2020 / 1$ & $0 / 0 \& 2 / 1$ & $1 / 1 \& 1 / 0$ & $0 / 0 \& 0 / 1$ & - & - \\
\hline V. $2020 / 1$ & $0 / 0 \& 1 / 0$ & $0 / 0 \& 2 / 2$ & $0 / 0 \& 2 / 0$ & $0 / 0 \& 1 / 1$ & $0 / 0 \& 1 / 0$ \\
\hline VI. 2020/1 & $0 / 0 \& 1 / 0$ & $0 / 0 \& 2 / 0$ & $0 / 0 \& 1 / 1$ & - & - \\
\hline VII. 2020/1 & $0 / 0 \& 1 / 0$ & $0 / 1 \& 1 / 0$ & $0 / 0 \& 1 / 0$ & - & - \\
\hline Total & $15 / 2 \& 11 / 5$ & $9 / 4 \& 28 / 11$ & $1 / 0 \& 16 / 11$ & $0 / 0 \& 9 / 4$ & $0 / 0 \& 3 / 1$ \\
\hline
\end{tabular}

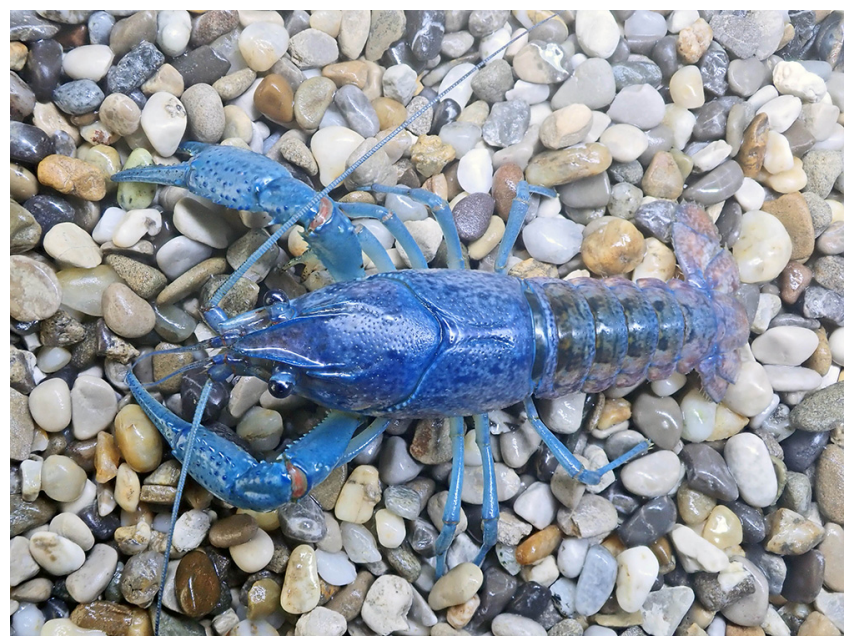

Fig. 2. Florida crayfish Procambarus alleni female caught in the Gombás brook, near Vác, Hungary.

analysis revealed this crayfish to be identical to a hitherto undescribed species of Cherax (similarity of COI: $100 \%$ KU821416; 16S rRNA: 100\% KU821431 - Bláha et al., 2016). The closest related species is $C$. pulcher, with a similarity of $93.2 \%$ (COI) and $96.4 \%$ (16S rRNA).
The second unidentified crayfish (Fig. 4) caught in October 2019 was a female measuring $97.2 \mathrm{~mm}$ TL, $41.3 \mathrm{~mm} \mathrm{CL}$ (GenBank accession numbers COI: MT833302, 16SrRNA: MT833288). Molecular analysis also revealed that this individual was similar to a scientifically undescribed species of Cherax (similarity of COI: $99.5 \%$ KJ950507; 16S rRNA: 100\% KJ920783 - Eprilurahman, 2014). Cherax pulcher was again found to be the closest described species (similarity of COI: 96.6\% KY654083; 16S rRNA: 98.1\% KY654091 Lukhaup et al., 2017).

The third crayfish caught (Fig. 4) in November 2019 was a female measuring $73.0 \mathrm{~mm}$ TL, $33.0 \mathrm{~mm}$ CL (GenBank accession numbers COI: MT833301, 16SrRNA: MT833287). Given its general characteristics and overall orange coloration, it was identified as $C$. holthuisi, an identification later confirmed by molecular methods (similarity of COI: $98.9 \%$ KU821421 - 16S rRNA: 100\% KU821433 - Bláha et al., 2016; 16S rRNA: 100\% KJ920801, KJ920804 - Eprilurahman, 2014).

The final two unidentified specimens caught in June 2020 were both females with body lengths of 94.9 and $100.2 \mathrm{~mm}$ (49.7 and 52.6 mm CL; GenBank accession numbers COI: MT833299, MT833300, 16SrRNA: MT833285, MT833286). Two other individuals of this species were recorded visually at the same time at sampling point 1 but not caught. Based on their general characteristics, morphology, and coloration, these 
individuals were determined as $C$. snowden (jun. syn. C. subterigneus; Fig. 4). Using molecular methods, great similarity was found with $C$. snowden (COI: 98.8 and $98.5 \%$ KT626459 - Lukhaup, 2015; 16S rRNA: 99.4\% KY654087 Lukhaup et al., 2017).

The GMYC and PTP analyses assigned individuals from this study to monophyletic clades corresponding in two cases

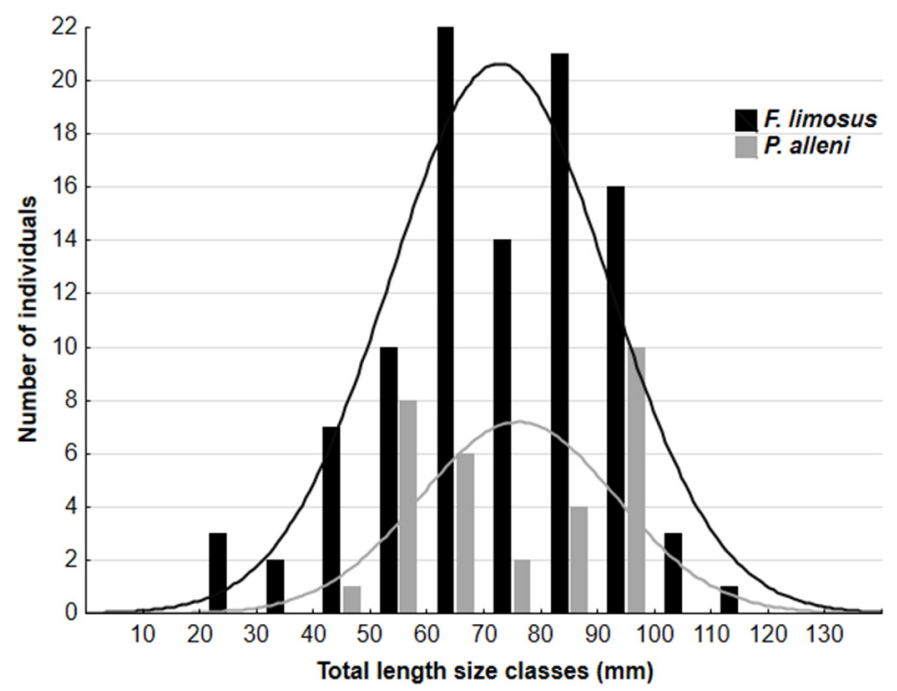

Fig. 3. Histogram of total body length size classes (mm) of the spinycheek crayfish Faxonius limosus and Florida crayfish Procambarus alleni at Gombás brook near Vác, Hungary, during the survey period (sampling points and sex merged). (individuals from November 2019 and June 2020) to C. snowden and C. holthuisi, respectively, with moderate support (0.57 and 0.63 , respectively). Two other individuals (January 2019 and October 2019) were clustered with scientifically undescribed species, albeit with strong support (0.84 and 0.95 , respectively). The only disparity was the assigning of GenBank individual KU821426 as a different species using PTP, whereas GMYC identified it as a C. warsamsonicus (Fig. 4).

\section{Discussion}

Thanks to their size, population density, omnivorous nature, and certain other biological features, crayfish have a great potential for colonizing and altering new environments, a trait that can give rise to biological invasions (Gherardi et al., 2011; Lodge et al., 2012). Recently, the pet trade (Faulkes, 2015a; Chucholl, 2013; Patoka et al., 2014) and related intentional and non-intentional releases have accelerated their spread, especially in Europe (Hossain et al., 2018; Jaklič and Vrezec, 2011; Patoka et al., 2017; Weiperth et al., 2017). This article provides evidence of the range of pet-traded crayfish species that can be detected in the wild and confirms that the pet trade represents an obvious introduction pathway that is highly difficult to control effectively (Patoka et al., 2018).

\subsection{Gombás brook}

Florida crayfish, also known as the Everglades crayfish, electric blue crayfish, or blue crayfish in the pet trade, are native to Florida, where they are ubiquitous, above all in the

Table 5. Városliget thermal pond, Budapest, Hungary. The dates (month and year) with number of captured adult females, males, and juveniles (when applicable) of captured crayfish species: red swamp crayfish Procambarus clarkii, marbled crayfish Procambarus virginalis, redclaw Cherax quadricarinatus, and other Cherax spp. Note that only females are present in the marbled crayfish.

\begin{tabular}{|c|c|c|c|c|}
\hline Date & P. clarkii & P. virginalis & C. quadricarinatus & other Cherax spp. \\
\hline I. 2019 & $0 / 2 / 0$ & $75 / 15$ & - & $0 / 1$ \\
\hline II. 2019 & $15 / 7 / 26$ & $19 / 22$ & $0 / 1$ & - \\
\hline III. 2019 & $6 / 21 / 39$ & $26 / 45$ & - & - \\
\hline IV. 2019 & $10 / 22 / 8$ & $42 / 11$ & - & - \\
\hline V. 2019 & $2 / 16 / 2$ & $16 / 3$ & - & - \\
\hline VI. 2019 & $16 / 28 / 10$ & $5 / 26$ & - & - \\
\hline VII. 2019 & $5 / 16 / 27$ & $11 / 16$ & - & - \\
\hline VIII. 2019 & $23 / 8 / 41$ & $11 / 22$ & $0 / 2$ & - \\
\hline IX. 2019 & $10 / 27 / 2$ & $12 / 36$ & $1 / 0$ & - \\
\hline X. 2019 & $14 / 28 / 11$ & $10 / 16$ & $0 / 2$ & $1 / 0$ \\
\hline XI. 2019 & $35 / 159 / 85$ & $120 / 85$ & $2 / 9$ & $1 / 0$ \\
\hline XII. 2019 & $9 / 26 / 23$ & $29 / 18$ & $2 / 3$ & - \\
\hline I. 2020 & $4 / 15 / 8$ & $16 / 3$ & $1 / 0$ & - \\
\hline II. 2020 & $12 / 19 / 5$ & $10 / 6$ & - & - \\
\hline III. 2020 & $16 / 8 / 0$ & $18 / 55$ & - & - \\
\hline IV. 2020 & $15 / 11 / 1$ & $16 / 49$ & - & - \\
\hline V. 2020 & $11 / 20 / 0$ & $20 / 39$ & - & - \\
\hline VI. 2020 & $12 / 9 / 13$ & $35 / 41$ & - & $2 / 0$ \\
\hline VII. 2020 & $29 / 23 / 0$ & $41 / 70$ & $2 / 1$ & $*$ \\
\hline Total & $244 / 465 / 311$ & $\mathbf{5 3 5 / 5 7 8}$ & $8 / 18$ & $4 / 1^{*}$ \\
\hline
\end{tabular}

* Two Cherax snowden individuals identified visually. 


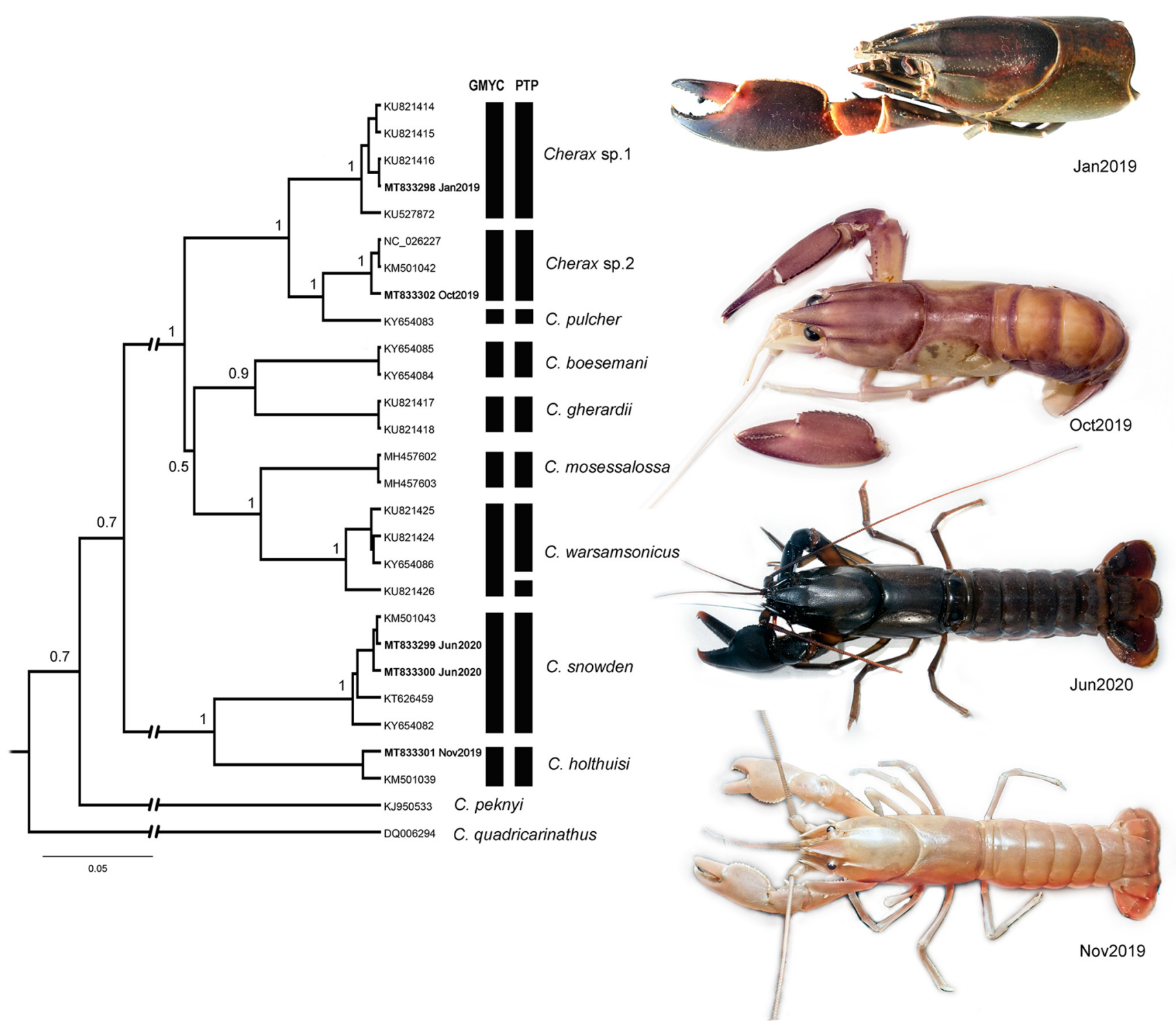

Fig. 4. Bayesian tree depicting the relationship between the Cherax species in the COI dataset. The species analyzed in this study are shown in bold text. Bayesian inference is displayed at each node. Each Cherax specimen is labelled with its GenBank code, including the specimens analyzed in this study. Full bars next to individuals indicate species status assigned by GMYC and PTP methods. The illustrations correspond to individuals found and analyzed in this study. Note that the second Cherax specimen from the top is ethanol-preserved and so does not fully show its natural coloration.

center and south of this state (Hobbs, 1942; Kushlan and Kushlan, 1979). To date, no population of this species has been recorded in any other US state (Taylor et al., 2007) or elsewhere in the world. Given its attractive blue coloration, it is popular as a pet and populations may occur near crayfish farms, especially if crayfish are bred in ponds. This may be the case of certain ornamental crayfish-producing countries in southeast Asia such as Indonesia (Yonvitner et al., 2020). To date, a single individual has been reported from France (Souty-Grosset et al., 2006) and Groß et al. (2008) captured a single large male in the river Rhine in Germany in March 2013.

The Florida crayfish is a medium-sized species whose carapace rarely exceeds $45 \mathrm{~mm}$ in length (Dorn and Trexler, 2007; Vanarman, 2003). In our survey, several individuals reached this maximum size, although none exceeded $10 \mathrm{~cm}$ TL (Fig. 3). The lifespan of this species is three to four years (Acosta and Perry, 2002). It occurs in a broad range of ephemeral as well as permanent waterbodies (Hendrix and Loftus, 2000; Hobbs, 1942) but prefers temporary waters and those that are still or very sluggish, or even littoral zones that dry out seasonally (Dorn and Volin, 2009; Hendrix and Loftus, 2000; Hobbs, 1942). Potential habitats thus include ephemeral pools and flooded marshes with short hydroperiods (flooded for less than nine months of the year) and salinities as high as 18 ppt (Conover and Reid, 1972; Hendrix and Loftus, 2000). Thus, it is the typical inhabitant of seasonally flooded marl prairie wetlands in the Everglades National Park, Florida (Acosta and Perry, 2000). During summer and autumn 
(the rainy seasons) it inhabits inundated shorelines with dense vegetation that reduces the threat of predation by fish and cannibalism. During the dry season (winter and spring), Florida crayfish move into existing burrows or construct new ones in diverse substrates, where it avoids desiccation and is able to reproduce. The young hatch in these burrows near the end of the dry season (April-May), where they remain with the adult females until the next flood, generally in June-July (Acosta and Perry, 2001; Dorn and Volin, 2009; Hendrix Jr et al. 1999; Hobbs, 1942; Jordan et al., 1996). This species influences community structures, alter landscapes, and as an omnivore enhances nutrient cycling. It is a predator as well as prey for many other organisms. It is faster growing and more aggressive than the slough crayfish Procambarus fallax and may outcompete it for food and shelter under certain environmental conditions. The biology of these two species is often contrasted in the literature (Dorn and Trexler, 2007; VanArman, 2011).

The evaluation of the biology and population status of the Florida crayfish present in the Gombás brook is of great interest. The number of sampled individuals is likely to represent the largest documented wild stock outside its native range. Three out of 13 females caught in September 2018 had glair glands, while three out of six females had eggs in October 2019, which completed successful embryogenesis in a home aquarium at room temperature in January 2019 (Tab. 4). This indicates that hatching at this locality in early spring is possible. However, it is unclear whether or not the eggs would develop successfully under natural winter temperatures. Notwithstanding, pooled biometric data reveal two different but abundant size groups at this locality (Fig. 3), which possibly coincide with two different age classes. However, a direct comparison of this species' life history in its native range is difficult due to substantially differing environmental conditions as well as the limited information gathered at the study site. Nevertheless, overwintering in two years does seem to have occurred. The size (CL in $\mathrm{mm}$ ) of caught individuals did not increase over time (order of month in the sampling campaign; slope -0.0042 , data not shown). Given the relatively short lifespan of the species (Acosta and Perry, 2002), only once released animals would reach senescence and grow in size during the two-year monitoring period which was not the case. This suggests that reproduction has taken place at the locality or that there is ongoing propagule pressure. Florida crayfish were mainly detected in the upper two sampling points, but one was also seen being eaten by a grey heron in the Danube floodplain (sampling point 5). Despite the high mobility of this predator, we presume herons can manipulate crayfish with ease and so this crayfish was probably consumed where it was caught. Assuming that the temperature requirements of Florida crayfish are similar to those of the closely related marbled crayfish (cf. Weiperth et al., 2019), it seems that even localities with natural or close-to-natural temperature regimes (non-thermal water bodies) are suitable for this species in this region. In light of the absence of juveniles, further monitoring is needed to clarify the status of this population, above all given that long-term propagule pressure cannot be entirely excluded.

Florida crayfish are a particularly popular crayfish species in the pet trade; its blue form, as seen in all the individuals from the Gombás brook (Fig. 2), is the most commonly marketed one. The species is available in markets in the United States (Faulkes, 2015b), Great Britain (Peay et al., 2010), the Netherlands (Soes and Koese, 2010), Slovakia (Lipták and Vitázková, 2015), and Turkey (Turkmen and Karadal, 2012). Taking national crayfish pet trade surveys into account, along with risk evaluation of species present in Germany, the Czech Republic, Hungary, and Ukraine, Florida crayfish are rarely to very commonly available, and are placed in a medium risk category by the Freshwater Invertebrate Invasiveness Scoring Kit scheme (Chucholl, 2013; Kotovska et al., 2016; Patoka et al., 2014; Weiperth et al., 2019). In terms of its potential environmental impact and management strategies, the Florida crayfish is included in the proposed Watch List for the Czech Republic (Pergl et al., 2016). Its role in the dissemination of the crayfish plague pathogen (cf. Svoboda et al., 2017) and its burrowing capacities (Dorn and Trexler, 2007; Hobbs, 1942) are two of the main potential impacts associated with the Florida crayfish.

The spiny-cheek crayfish that co-occurs with the Florida crayfish in Gombás is well known as an invasive species in Hungary (Györe et al., 2013; Ludányi et al., 2016). The data gathered in this study provide a possibly interesting insight into the reproduction biology of this relatively well-studied species (Buřič et al., 2013; Pacioglu et al., 2020; Pârvulescu et al., 2015). Spiny-cheek crayfish are known to have two peaks of mating activity, first in September-October and then in early spring. Mating activity is suppressed to a certain degree in winter and ovulation take place shortly after spring mating. Juveniles hatch in May-June (Buřič et al., 2013; Holdich, 2002; Kozák et al., 2006; Kozák et al., 2007). The presence of glair glands in September 2018 and the remains of eggshells in June 2019 agree with this generally known pattern of spinycheek crayfish reproduction. However, we have found no records of egg ovulation in the autumn in this species (noted in one out of five and three out of eleven females in October 2018 and 2019, respectively). The success of this alternative reproduction mode is unclear. Considering the overlap in the timing of Florida crayfish oviposition mentioned above, hatching could take place in early spring. However, there is no information on spiny-cheek crayfish embryogenesis in low winter temperatures. If it is possible, it may take place in combination with the so-called diapause known in coldwater species such as the signal crayfish and European astacids. If development is not disrupted and hatching occurs in late autumn/early winter, the overwintering of small juveniles is equally questionable. Taking into account available information, this reproduction mode is probably only exceptional and most likely to be unsuccessful. However, it might also have been overlooked, as exemplified by the facultative parthenogenesis documented by Buřič et al. (2011). An inlet with municipal waters from the nearby Vác affects the first sampling point and, in fact, dominates the water flow in the Gombás during drought periods, especially in summer. We are unaware and to what extent these municipal waters are cleaned as part of the local sewage treatment plan. However, these waters have higher average temperatures, especially during the winter, which will presumably enable eggs to develop or juveniles to survive. The coldest temperature observed in February 2020 was $7.2^{\circ} \mathrm{C}$ at the first sampling point, which slowly fell to $3.2^{\circ} \mathrm{C}$ at sampling point 5 (Tab. 2). It is unclear whether or not this temperature alteration alone is 
enough to completely reverse the normal pattern of spinycheek crayfish ovulation in early spring. Furthermore, due to insufficient cleansing efficiency during water treatment, municipal waters also contain numerous pollutants including hormonally active compounds that could disrupt reproduction processes in aquatic organisms (Grabicova et al., 2015; Kumar et al., 2015), thereby potentially giving rise to the documented autumn oviposition in the spiny-cheek crayfish.

Given its parthenogenetic mode of reproduction (Martin et al., 2007), the discovery of even a single marbled crayfish in the Danube floodplain downstream of the Gombás brook is enough to set alarm bells ringing as it would be evidence of a population spread of this invasive species (Vodovsky et al., 2017 and reference therein). To our knowledge, this is the northernmost occurrence of the species in the Danube in Hungary (at km 1678). Numerous reports situate this species at

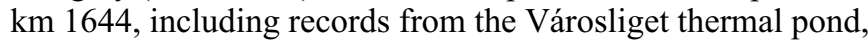
the thermal pond on Margaret Island, the Dera and Barát brooks including their confluences with the Danube, and several arms of the Danube in this region. Other locations are also known from Hungary (Lökkös et al., 2016; Szendőfi et al., 2018; Weiperth et al., 2015; Weiperth et al., 2020). Bearing in mind the presumed spread of the marbled crayfish around Bratislava, Slovakia (Lipták et al., 2017) and a recent report from Vienna, Austria (Moog et al., 2018), the scenario of a potentially rapid spread of this species throughout the midcourse of the River Danube is now much more likely. This process might be also accelerated by further introductions elsewhere in the broader region (Pârvulescu et al., 2017; Samardžić et al., 2014).

\subsection{Városliget pond}

As the number of non-native crayfish species increases and their ranges expand, new and often surprising species assemblages appear. This provides ground for comparative research into the factors that could determine the success of particular species (Jackson et al., 2014; Kouba et al., 2016; Veselý et al., 2015). However, studies that undertake simultaneous comparisons of multiple non-native crayfish species in natural settings are as yet few and far between (Herrmann et al., 2018; Jackson, 2015). Therefore, places where various species coincide are of particular interest as they can provide a better understanding of such relationships. Given its array of non-native crayfish species, Városliget is such a locality. This site is apparently dominated be two notorious invasive species, the marbled and red swamp crayfish. Marbled crayfish first appeared in 2014, when several large individuals $(\sim 15 \mathrm{~cm}$ TL) were noted. A single male red swamp crayfish was first recorded in 2015, and 17 individuals were detected in 2016. Since then, both species have become numerous. Marbled crayfish do not exceed $10 \mathrm{~cm}$ TL and frequently inhabit algal surfaces on concrete walls (Weiperth et al., 2015). It seems that the conditions are more suitable for red swamp crayfish, whose mean adult sizes are larger (data not shown). It is likely that this site is an important source of the red swamp crayfish that inhabit the adjacent River Danube. Numerous reports exist of this crayfish from other places in the country, including distant locations along the Danube and in the vicinity of Budapest, where it is found along $50 \mathrm{~km}$ of the brooks Barát, Dera, and Sulák and their confluences with the Danube. These reports thus most probably reveal the continuous occurrence of this species (Gál et al., 2018; Szendőfi et al., 2018; Weiperth et al., 2015, 2020).

Redclaws have been reported from several places in Hungary (Weiperth et al., 2019, 2020) and Városliget is where this species is most numerous. Despite the relatively low sampling effort and the undoubtably enormous competitive pressure exerted by the dominant marbled and red swamp crayfish, 26 redclaws were recorded at Városliget, which suggests that hundreds of this crayfish are present here. Nevertheless, its population status remains unclear given that no documented females with glair glands, eggs, or juveniles have ever been found. If breeding does not in fact take place, the propagule pressure must be enormous in this locality. The high susceptibility to the crayfish plague might prevent the establishment of Cherax species at this site (Marino et al., 2014; Svoboda et al., 2017; Unestam, 1975). However, if the original marbled and red swamp crayfish stocks were plaguefree, this consideration would be irrelevant. High temperatures (Oidtmann et al., 2002; Svoboda et al., 2020) and the specific water chemistry (Svoboda et al., 2014; Unestam, 1969) might also hinder the proliferation of disease at this locality; however, more research in this field is still needed in order to gather more relevant data.

Although the BLAST search helped identify the most similar sequences/species of all the other Cherax individuals captured at Városliget, only individuals caught in November 2019 and June 2020 could be assigned to scientifically described species, namely $C$. holthuisi and $C$. snowden, respectively. The habitus of these individuals was distinctive and was confirmed by molecular analysis. The remaining individuals shared the habitus of species resembling $C$. boesemani and C. pulcher and the use of molecular tools confirmed their identification. None of these individuals matched the sequences of $C$. boesemani from the type locality (similarity: COI: 90\%; 16S rRNA: $94.5 \%$ for both individuals) recently published by Lukhaup et al. (2017). Although both were most similar to $C$. pulcher, according to species delimitation analysis (Fig. 4) and molecular divergences (January 2019: 6.5\% and October 2019: 3.5\%) it is likely that neither of these crayfish belongs to this species. Thus, based on Bayesian inference and species delimitation methods, each belongs to different, as yet scientifically undescribed species. New Guinean Cherax species diversity is much higher than expected and distinct morphological characteristics are not sufficient for distinguishing this diversity (Bláha et al., 2016). The fact that numerous species descriptions in the past were performed before the molecular definition of type specimens was possible further complicates species assignment. Here, we identified individuals of two different yet hitherto undescribed species, which underlines the need to revise New Guinean Cherax species biodiversity and define new suitable morphological characteristics that could be helpful for species identification (Patoka, 2020).

Given their proximity to $C$. pulcher, the native range of the two undescribed species will probably be around the Bird's Head Peninsula, West Papua Province, Indonesia, which is also where $C$. holthuisi and $C$. snowden are found (Bláha et al., 2016; Patoka, 2020). Thanks to their coloration, these endemic Cherax species are particularly attractive for the pet trade and are usually wild-caught in their native ranges 
(Faulkes, 2015a; Patoka, 2020; Patoka et al., 2015a). While the indirect environmental impact of these species cannot be entirely ruled out (as exemplified by the introduction of the crayfish plague from North America into Europe in the past; Svoboda et al., 2017), these species should not be considered to be problematical in continental climates (like Hungary's) as their temperature requirements prevent their spread beyond thermal waters and their fecundity is thought to be low. However, a more detailed assessment of their situation in Europe is hampered by a lack of information regarding their life histories. To our knowledge, this is the first ever published report of releases of New Guinean endemic crayfish species (other than the redclaw). This circumstance is probably uncommon as the retail prices of even small specimens of these highly valued species often exceed 15 EUR per individual (Chucholl, 2013; Patoka et al., 2015b).

\section{Conclusion}

We report here the monitoring of two localities in Hungary with three and seven co-occurring non-native crayfish species, which is evidence that non-native crayfish introductions into Europe are apparently on the increase. Urban and especially thermal waters have become hotspots of crayfish allodiversity and even high market prices do not completely curb such releases. These sites are worth closer investigation as they can provide us with contextual information on how particular species will coexist, which will help gather information for predicting future changes once they become more widespread. Furthermore, these localities are places from where these species disperse. Given that the eradication methods for established non-native crayfish populations are only feasible for a very narrow range of specific conditions, prevention remains the best measure for halting any increase in non-native crayfish species in Europe. Besides, research into insufficiently known biodiversity of New Guinean Cherax spp. is still needed.

Acknowledgements. This study was supported by the Czech Science Foundation (No. 19-04431S) and the National Research, Development, and Innovation Office (No. NVKP 16-1-2016-0003). The authors would like to thank Edit Répás, Enikő Réka Balogh, and Veronika Gábris for help with the fieldwork.

\section{References}

Acosta CA, Perry SA. 2000. Differential growth of crayfish Procambarus alleni in relation to hydrological conditions in marl prairie wetlands of Everglades National Park, USA. Aquat Ecol 34: 389-395.

Acosta CA, Perry SA. 2001. Impact of hydropattern disturbance on crayfish population dynamics in the seasonal wetlands of Everglades National Park, USA. Aquat Conserv Marine Freshw Ecosyst 11: 45-57.

Acosta CA, Perry SA. 2002. Spatio-temporal variation in crayfish production in disturbed marl prairie marshes of the Florida Everglades. J Freshw Ecol 17: 641-650.

Bláha M, Patoka J, Japoshvili B, Let M, Kouba A, Buřič M, Mumladze L. 2020. Genetic diversity, phylogenetic position and morphometric analysis of Astacus colchicus (Decapoda, Astacidae): a new insight into Eastern European crayfish fauna. Integr Zool, doi: 10.1111/1749-4877.12493.

Bláha M, Patoka J, Kozák P, Kouba A. 2016. Unrecognized diversity in New Guinean crayfish species (Decapoda, Parastacidae): The evidence from molecular data. Integr Zool 11: 447-458.

Bláha M, Uzhytchak M, Bondarenko V, Policar T. 2017. The least known European native crayfish Astacus pachypus (Rathke, 1837) revealed its phylogenetic position. Zoologischer Anzeiger 267: 151-154.

Buřič M, Hulák M, Kouba A, Petrusek A, Kozák P. 2011. A successful crayfish invader is capable of facultative parthenogenesis: a novel reproductive mode in decapod crustaceans. Plos One 6: e20281.

Buřič M, Kouba A, Kozak P. 2013. Reproductive plasticity in freshwater invader: from long-term sperm storage to parthenogenesis. Plos One 8: e77597.

Conover M, Reid GK. 1972. A study of Procambarus alleni in the Everglades. Everglades National Park, unpublished report from the University of Miami, Miami, FL, USA.

Crandal KA, Buhay JE. 2008. Global diversity of crayfish (Astacidae, Cambaridae, and Parastacidae-Decapoda) in freshwater. Hydrobiologia 595: 295-301.

Crandal KA, De Grave S. 2017. An updated classification of the freshwater crayfishes (Decapoda: Astacidea) of the world, with a complete species list. J Crustacean Biol 37: 615-653.

Crandal KA, Fitzpatrick Jr J. 1996. Crayfish molecular systematics: using a combination of procedures to estimate phylogeny. System Biol 45: 1-26.

Chucholl C. 2013. Invaders for sale: trade and determinants of introduction of ornamental freshwater crayfish. Biol Invas 15: $125-141$.

Dorn NJ, Trexler JC. 2007. Crayfish assemblage shifts in a large drought-prone wetland: the roles of hydrology and competition. Freshw Biol 52: 2399-2411.

Dorn NJ, Volin JC. 2009. Resistance of crayfish (Procambarus spp.) populations to wetland drying depends on species and substrate. J North Am Bentholog Soc 28: 766-777.

Drummond AJ, Rambaut A. 2007. BEAST: Bayesian evolutionary analysis by sampling trees. BMC Evolut 7: 214.

Eprilurahman R. 2014. Molecular taxonomy and evolution of freshwater crayfish of the genus Cherax (Decapoda: Parastacidae) from northern Australia and New Guinea. Charles Darwin University, Research Institute for the Environment and Livelihoods: 154 .

EU. 2014. Regulation (EU) No 1143/2014 of the European Parliament and of the Council of 22 October 2014 on the prevention and management of the introduction and spread of invasive alien species. Offic J Eur Union 57: 35.

EU. 2016. Commission Implementing Regulation (EU) 2016/1141 of 13 July 2016 adopting a list of invasive alien species of Union concern pursuant to Regulation (EU) No 1143/2014 of the European Parliament and of the Council. Offic J Eur Union 189: 4-8.

European Commission. 2009. Common Implementation Strategy for the Water Framework Directive (2000/60/EC); Guidance document n.o 7. Monitoring under the Water Framework Directive; circabc. europa.eu/sd/a/63f7715f-0f45-4955-b7cb-58ca305e42a8/Guidance $\% 20 \mathrm{No} \% 207 \% 20-\% 20$ Monitoring\%20(WG\%202.7).pdf.

Faulkes Z. 2015a. The global trade in crayfish as pets. Crustacean Res 44: 75-92.

Faulkes Z. 2015b. Marmorkrebs (Procambarus fallax f. virginalis) are the most popular crayfish in the North American pet trade. Knowl Manag Aquatic Ecosyst 416: 20. 
Folmer O, Black M, Hoeh W, Lutz R, Vrijenhoek R. 1994. DNA primers for amplification of mitochondrial cytochrome $\mathrm{c}$ oxidase subunit I from diverse metazoan invertebrates. Mol Mar Biol Biotechnol 3: 294-299.

Fujisawa T, Barraclough TG. 2013. Delimiting species using singlelocus data and the Generalized Mixed Yule Coalescent approach: a revised method and evaluation on simulated data sets. System Biol 62: 707-724.

Gál B, Gábris V, Csányi B, Cser B, Danyik T, Farkas A, Farkas J, Gebauer R, Répás E, Szajbert B, Kouba A, Patoka J, Weiperth A. 2018. A vörös mocsárrák Procambarus clarkii (Girard, 1852) jelenlegi elterjedése és hatása a Duna egyes magyarországi befolyóinak halfaunájára [Present distribution of the invasive red swamp crayfish Procambarus clarkii (Girard, 1852) and its effects on the fish fauna assemblages in some tributaries of the Hungarian section of the River Danube]. Pisces Hungarici 12: 71-76.

Gherardi F, Acquistapace P. 2007. Invasive crayfish in Europe: the impact of Procambarus clarkii on the littoral community of a Mediterranean lake. Freshw Biol 52: 1249-1259.

Gherardi F, Aquiloni L, Dieguez-Uribeondo J, Tricarico E. 2011. Managing invasive crayfish: is there a hope? Aquat Sci 73: $185-200$.

Grabicova K, Grabic R, Blaha M, Kumar V, Cerveny D, Fedorova G, Randak T. 2015. Presence of pharmaceuticals in benthic fauna living in a small stream affected by effluent from a municipal sewage treatment plant. Water Res 72: 145-153.

Groß H, Burk C, Hil A. 2008. Die Flusskrebsfauna in NRW. Nat NRW 4: $52-56$

Györe K, Józsa V, Gál D. 2013. The distribution of crayfish (Decapoda: Astacidae, Cambaridae) population in Cris and Mures rivers crossing the Romanian-Hungarian border. Aquacult Aquar Conserv Legisl 6: 18-26.

Hendrix AN, Loftus WF. 2000. Distribution and relative abundance of the crayfishes Procambarus alleni (Faxon) and P. fallax (Hagen) in southern Florida. Wetlands 20: 194-199.

Hendrix Jr N, Loftus WF, Armstrong D. 1999. Life history, ecology, and interactions of Everglades crayfishes in response to hydrological restoration. US Geological Survey Program on the South Florida Ecosystem, 38-39.

Herrman A, Schnabler A, Martens A. 2018. Phenology of overland dispersal in the invasive crayfish Faxonius immunis (Hagen) at the Upper Rhine River area. Knowl Manag Aquat Ecosyst 419: 30.

Hobbs HH. 1942. The crayfishes of Florida. University of Florida under the auspices of the Committee on University Publications.

Holdich DM. 2002. Biology of Freshwater Crayfish. Blackwell Science Oxford.

Holdich DM, Reynolds JD, Souty-Grosset C, Sibley PJ. 2009. A review of the ever increasing threat to European crayfish from non-indigenous crayfish species. Knowl Manag Aquat Ecosyst 394-395: 11.

Hossain, MS, Patoka J, Kouba A, Buřič M. 2018. Clonal crayfish as biological model: a review on marbled crayfish. Biologia 73: 841-855.

Jackson MC. 2015. Interactions among multiple invasive animals. Ecology 96: 2035-2041.

Jackson MC, Jones T, Milligan M, Sheath D, Taylor J, Ellis A, England J, Grey J. 2014. Niche differentiation among invasive crayfish and their impacts on ecosystem structure and functioning. Freshw Biol 59: 1123-1135.

Jaklič M, Vrezec A. 2011. The first tropical alien crayfish species in European waters: the redclaw Cherax quadricarinatus
(Von Martens, 1868) (Decapoda, Parastacidae). Crustaceana 84: 651-665.

Jelić M, Klobučar GI, Grandjean F, Puillandre N, Franjević D, Futo M, Amouret J, Maguire I. 2016. Insights into the molecular phylogeny and historical biogeography of the white-clawed crayfish (Decapoda, Astacidae). Mol Phylogenet Evol 103: 26-40.

Jordan F, DeLeon CJ, McCreary AC. 1996. Predation, habitat complexity, and distribution of the crayfish Procambarus alleni within a wetland habitat mosaic. Wetlands 16: 452-457.

Kearse M, Moir R, Wilson A, Stones-Havas S, Cheung M, Sturrock S, Buxton S, Cooper A, Markowitz S, Duran C. 2012. Geneious Basic: an integrated and extendable desktop software platform for the organization and analysis of sequence data. Bioinformatics 28: 1647-1649.

Klobučar GIV, Podnar M, Jelić M, Franjević D, Faller M, Štambuk A, Gottstein S, Simić V, Maguire I. 2013. Role of the Dinaric Karst (western Balkans) in shaping the phylogeographic structure of the threatened crayfish Austropotamobius torrentium. Freshw Biol 58: 1089-1105.

Kotovska G, Khrystenko D, Patoka J, Kouba A. 2016. East European crayfish stocks at risk: arrival of non-indigenous crayfish species. Knowl Manag Aquat Ecosyst 37.

Kouba A, Petrusek A, Kozák P. 2014. Continental-wide distribution of crayfish species in Europe: update and maps. Knowl Manag Aquat Ecosyst 413: 5.

Kouba A, Tíkal J, Císař P, Veselý L, Fořt M, Př́iborský J, Patoka J, Buřič M. 2016. The significance of droughts for hyporheic dwellers: evidence from freshwater crayfish. Sci Rep 6: 26569.

Kovács K, Nagy P, Mayer R. 2015. Adatok a tízlábú rákok (Decapoda: Astacidae, Cambaridae) északnyugat-magyarországi előfordulásához. Egy Procambarus faj első előkerülése természetes élőhelyéről Magyarországon [Contribution to the Decapoda (Astacidae, Cambaridae) fauna of Northwestern Hungary. The first occurrence of a Procambarus species]. Acta Biol Debrec Oecolog Hungarica 33: 177-186.

Kozák P, Buřič M, Policar T. 2006. The fecundity, time of egg development and juvenile production in spiny-cheek crayfish (Orconectes limosus) under controlled conditions. Bulletin Français de la Pêche et de la Pisciculture 380-381: 1171-1182.

Kozák P, Hulák M, Policar T, Tichý F. 2007. Studies of annual gonadal development and gonadal ultrastructure in spiny-cheek crayfish (Orconectes limosus). Bulletin Français de la Pêche et de la Pisciculture 384: 15-26.

Kumar V, Johnson, AC, Trubiroha A, Tumová J, Ihara M, Grabic R, Kloas W, Tanaka H, Kroupová HK. 2015. The challenge presented by progestins in ecotoxicological research: a critical review. Environ Sci Technol 49: 2625-2638.

Kushlan JA, Kushlan MS. 1979. Observations on crayfish in the Everglades, Florida, USA. Crustaceana. Supplement 115-120.

Lipták B, Mojžišová M, Grul'a D, Christophoryová J, Jablonski D, Bláha M, Petrusek A, Kouba A. 2017. Slovak section of the Danube has its well-established breeding ground of marbled crayfish Procambarus fallax f. virginalis. Knowl Manag Aquat Ecosyst 418: 40.

Lipták B, Vitázková B. 2015. Beautiful, but also potentially invasive. Ekológia (Bratislava) 34: 155-162.

Lodge DM, Deines A, Gherardi F, Yeo DCJ., Arcella T, Baldridge AK, Barnes MA, Chadderton WL, Feder JL, Gantz CA, Howard GW, Jerde CL, Peters BW, Peters JA, Sargent LW, Turner CR, Wittman ME, Zeng Y. 2012. Global Introductions of Crayfishes: Evaluating the Impact of Species Invasions on Ecosystem Services. Annu Rev Ecol Evol Syst 43: 449-472. 
Lodge DM, Taylor CA, Holdich DM, Skurdal J. 2000. Nonindigenous crayfishes threaten North American freshwater biodiversity: Lessons from Europe. Fisheries 25: 7-20.

Lőkkös A, Müller T, Kovács K, Várkonyi L, Specziár A, Martin P. 2016. The alien, parthenogenetic marbled crayfish (Decapoda: Cambaridae) is entering Kis-Balaton (Hungary), one of Europe's most important wetland biotopes. Knowl Manag Aquat Ecosyst 417: 16.

Lovrenčić L, Bonassin L, Boštjančić LL, Podnar M, Jelić M, Klobučar G, Jaklič M, Slavevska-Stamenković V, Hinić J, Maguire I. 2020. New insights into the genetic diversity of the stone crayfish: taxonomic and conservation implications. $B M C$ Evolutionary Biology 20: 146.

Ludányi M, Peeters EE, Kis B, Roessink I. 2016. Distribution of crayfish species in Hungarian waters. Glob Ecol Conserv 8: 254-262.

Lukhaup C. 2015. Cherax (Astaconephrops) pulcher, a new species of freshwater crayfish (Crustacea, Decapoda, Parastacidae) from the Kepala Burung (Vogelkop) Peninsula, Irian Jaya (West Papua), Indonesia. ZooKeys 1-10.

Lukhaup C, Eprilurahman R, von Rintelen T. 2017. Cherax warsamsonicus, a new species of crayfish from the Kepala Burung (Vogelkop) peninsula in West Papua, Indonesia (Crustacea, Decapoda, Parastacidae). ZooKeys 151-167.

Maguire I, Podnar M, Jelic M, Stambuk A, Schrimpf A, Schulz H, Klobucar G. 2014. Two distinct evolutionary lineages of the Astacus leptodactylus species-complex (Decapoda: Astacidae) inferred by phylogenetic analyses. Invertebr Syst 28: 117-123.

Marino F, Pretto T, Tosi F, Monaco S, De Stefano C, Manfrin A, Quaglio F. 2014. Mass mortality of Cherax quadricarinatus (von Martens, 1868) reared in Sicily (Italy): crayfish plague introduced in an intensive farming. Freshw Crayfish 20: 93-96.

Martin P, Dorn NJ, Kawai T, van der Heiden C, Scholtz G. 2010. The enigmatic Marmorkrebs (marbled crayfish) is the parthenogenetic form of Procambarus fallax (Hagen, 1870). Contrib Zool 79: 107-118.

Martin P, Kohlman K, Scholtz G. 2007. The parthenogenetic Marmorkrebs (marbled crayfish) produces genetically uniform offspring. Naturwissenschaften 94: 843-846.

Momot WT. 1995. Redefining the role of crayfish in aquatic ecosystems. Rev Fish Sci 3: 33-63.

Moog O, Leitner P, Huber T, Rabitsch W, Graf W. 2018. Marbled crayfish (Procambarus virginalis Lykow, 2017) - a supplement to the list of Aquatic Invertebrate Neozoa in Austria.

Oidtman B, Heitz E, Rogers D, Hoffman RW. 2002. Transmission of crayfish plague. Diseases Aquat Organ 52: 159-167.

Pacioglu O, Theissinger K, Alexa A, Samoilă C, Sîrbu O-I, Schrimpf A, Zubrod JP, Schulz R, Pîrvu M, Lele S-F. 2020. Multifaceted implications of the competition between native and invasive crayfish: a glimmer of hope for the native's long-term survival. Biol Invas 22: 827-842.

Pârvulescu L. 2019. Introducing a new Austropotamobius crayfish species (Crustacea, Decapoda, Astacidae): A Miocene endemism of the Apuseni Mountains, Romania. Zool Anzeiger 279: 94-102.

Pârvulescu L, Pérez-Moreno JL, Panaiotu C, Drăguț L, Schrimpf A, Popovici ID, Zaharia C, Weiperth A, Gál B, Schubart CD. 2019. A journey on plate tectonics sheds light on European crayfish phylogeography. Ecol Evolut 9: 1957-1971.

Pârvulescu L, Pîrvu M, Morosan L-G., Zaharia C. 2015. Plasticity in fecundity highlights the females' importance in the spiny-cheek crayfish invasion mechanism. Zoology 118: 424-432.
Pârvulescu L, Togor A, Lele S-F., Scheu S, Șinca D, Panteleit J. 2017. First established population of marbled crayfish Procambarus fallax (Hagen, 1870) f. virginalis (Decapoda, Cambaridae) in Romania. BioInvas Record 6: 357-362.

Patoka J. 2020. Crayfish of New Guinea: Current status, exploitation and threats. In: Ribeiro, FB (ed.), Evolution, Habitat and Conservation Strategies. Nova: 43-70.

Patoka J, Bláha M, Kalous L, Kouba A. 2017. Irresponsible vendors: Non-native, invasive and threatened animals offered for garden pond stocking. Aquat Conserv 27: 692-697.

Patoka J, Bláha M, Kouba A. 2015a. Cherax (Cherax) subterigneus, a new crayfish (Decapoda: Parastacidae) from West Papua, Indonesia. J Crustacean Biol 35: 830-838.

Patoka J, Buřič M, Kolář V, Bláha M, Petrtýl M, Franta P, Tropek R, Kalous L, Petrusek A, Kouba A. 2016. Predictions of marbled crayfish establishment in conurbations fulfilled: evidences from the Czech Republic. Biologia 71: 1380-1385.

Patoka J, Kalous L, Kopecký O. 2014. Risk assessment of the crayfish pet trade based on data from the Czech Republic. Biol Invas 16: 2489-2494.

Patoka J, Kalous L, Kopecký O. 2015b. Imports of ornamental crayfish: the first decade from the Czech Republic's perspective. Knowl Manag Aquat Ecosyst 416: 4.

Patoka J, Magalhães ALB., Kouba A, Faulkes Z, Jerikho R, Vitule JRS. 2018. Invasive aquatic pets: failed policies increase risks of harmful invasions. Biodivers Conserv 27: 3037-3046.

Peay S, Holdich D, Brickland J. 2010. Risk assessments of nonindigenous crayfish in Great Britain. Freshw Crayfish 17: 109-122.

Pergl J, Sádlo J, Petrusek A, Laštuvka Z, Musil J, Perglová I, Šanda R, Šefrová H, Šíma J, Vohralík V. 2016. Black, Grey and Watch Lists of alien species in the Czech Republic based on environmental impacts and management strategy. NeoBiota 28: 1-37.

Rambaut A, Suchard MA, Xie D, Drummond AJ. 2014. Tracer v1.6, Available from http://beast.bio.ed.ac.uk/Tracer.

Richman NI, Boehm M, Adams SB, Alvarez F, Bergey EA, Bun JJS, Burnham Q, Cordeiro J, Coughran J, Crandal KA, Dawkins KL, DiStefano RJ, Doran NE, Edsman L, Eversole AG, Fuereder L, Furse JM, Gherardi F, Hamr P, Holdich DM, Horwitz P, Johnston K, Jones CM, Jones JPG, Jones RL, Jones TG, Kawai T, Lawler S, Lopez-Mejia M, Miller RM, Pedraza-Lara C, Reynolds JD, Richardson AMM, Schultz MB, Schuster GA, Sibley PJ, SoutyGrosset C, Taylor CA, Thoma RF, Walls J, Walsh TS, Collen B. 2015. Multiple drivers of decline in the global status of freshwater crayfish (Decapoda: Astacidea). Philos Trans Royal Soc B 370: 20140060.

Samardžić M, Lucić A, Maguire I, Hudina S. 2014. The first record of the marbled crayfish (Procambarus fallax (Hagen, 1870) $\mathrm{f}$. virginalis) in Croatia. Crayfish News 36: 4-4.

Seebens H, Blackburn TM, Dyer EE, Genovesi P, Hulme PE, Jeschke JM, Pagad S, Pyšek P, Winter M, Arianoutsou M. 2017. No saturation in the accumulation of alien species worldwide. Nat Commun 8: 14435.

Seprős R, Farkas A, Sebestyén A, Lőkkös A, Kelbert B, Gál B, Puky M, Weiperth A. 2018. Current status and distribution of non-native spiny cheek crayfish (Faxonius limosus Rafinesque, 1817) in Lake Balaton. Hungarian Agric Res 27: 20-26.

Simberlof D, Martin J-L., Genovesi P, Maris V, Wardle DA, Aronson J, Courchamp F, Galil B, García-Berthou E, Pascal M. 2013. Impacts of biological invasions: what's what and the way forward. Trends Ecol Evol 28: 58-66.

Soes M, Koese B. 2010. Invasive freshwater crayfish in the Netherlands: a preliminary risk analysis. TRCPD/2010/0001, 
Ministery of Agriculture, Nature and Food Quality, Leiden, The Netherlands.

Souty-Grosset C, Holdich DM, Noël PY, Reynolds J, Haffner P. 2006. Atlas of Crayfish in Europe. Muséum national d'Histoire naturelle, Paris.

Svoboda J, Fischer D, Kozubíková-Balcarová E, Štástková A, Bručková M, Kouba A, Petrusek A. 2020. Experimental evaluation of the potential for crayfish plague transmission through the digestive system of warm-blooded predators. J Fish Dis 43: 129-138.

Svoboda J, Mrugała A, Kozubíková-Balcarová E, Petrusek A. 2017. Hosts and transmission of the crayfish plague pathogen Aphanomyces astaci: a review. J Fish Dis 40: 127-140.

Svoboda J, Strand DA, Vralstad T, Grandjean F, Edsman L, Kozak P, Kouba A, Fristad RF, Koca SB, Petrusek A. 2014. The crayfish plague pathogen can infect freshwater-inhabiting crabs. Freshw Biol 59: 918-929.

Szendőfi B, Bérces S, Csányi B, Gábris V, Gál B, Gönye Z, Répás E, Seprős R, Tóth B, Kouba A, Patoka J, Weiperth A. 2018. Egzotikus halfajok és decapodák a Barát-és Dera-patakban, valamint a torkolatuk dunai élöhelyein /Occurrence of exotic fish and crayfish species in Barát and Dera creeks and their adjacent section of the River Danube. Pisces Hungarici 47-51.

Taylor CA, DiStefano RJ, Larson ER, Stoeckel J. 2019. Towards a cohesive strategy for the conservation of the United States' diverse and highly endemic crayfish fauna. Hydrobiologia 846: 39-58.

Taylor CA, Schuster GA, Cooper JE, DiStefano RJ, Eversole AG, Hamr P, Hobbs HH, III, Robison HW, Skelton CE, Thoma RE. 2007. Feature: Endangered species - A reassessment of the conservation status of crayfishes of the united states and Canada after 10+years of increased awareness. Fisheries 32: 372-389.

Turkmen G, Karadal O. 2012. The survey of the imported freshwater decapod species via the ornamental aquarium trade in Turkey. $J$ Animal Veterin Adv 11: 2824-2827.

Twardochleb LA, Olden JD, Larson ER. 2013. A global meta-analysis of the ecological impacts of nonnative crayfish. Freshw Sci 32: $1367-1382$.

Unestam T. 1969. On the adaptation of Aphanomyces astaci as a parasite. Physiol Plant 22: 221-235.

Unestam T. 1975. Defence reactions in and susceptibility of Australian and New Guinean freshwater crayfish to Europeancrayfish-plague fungus. Aust J Exp Biol Med Sci 53: 349-359.

Ungureanu E, Mojžišová M, Tangerman M, Ion MC, Pârvulescu L, Petrusek A. 2020. The spatial distribution of Aphanomyces astaci genotypes across Europe: Introducing the first data from Ukraine. Freshw Crayfish 25: 77-87.

Vanarman PG. 2003. Biology and ecology of epigean crayfish that inhabit Everglades environments Procambarus alleni (Faxon) and Procambarus fallax (Hagen). Nova Southeastern University, Fort Lauderdale, FL: 173.

VanArman PG. 2011. Role of native crayfish, Procambarus alleni (Faxon) and Procambarus fallax (Hagen), in everglades food webs: a literature review and conceptual model. Florida Sci 74: 100-125.

Veselý L, Buřič M, Kouba A. 2015. Hardy exotics species in temperate zone: can "warm water" crayfish invaders establish regardless of low temperatures? Sci Rep 5: 16340.

Vodovsky N, Patoka J, Kouba A. 2017. Ecosystem of Caspian Sea threatened by pet-traded non-indigenous crayfish. Biol Invas 19: 2207-2217.

Vogt G, Falckenhayn C, Schrimpf A, Schmid K, Hanna K, Panteleit J, Helm M, Schulz R, Lyko F. 2015. The marbled crayfish as a paradigm for saltational speciation by autopolyploidy and parthenogenesis in animals. Biol Open 4: 1583-1594.

Weiperth A, Csányi B, Gál B, György Á, Szalóky Z, Szekeres J, Tóth B, Puky M. 2015. Egzotikus rák-, hal-és kétéltúfajok a Budapest környéki víztestekben [Exotic crayfish, fish and amphibian species in various water bodies in the region of Budapest]. Pisces Hungarici 9: 65-70.

Weiperth A, Gál B, Kuř́íková P, Bláha M, Kouba A, Patoka J. 2017. Cambarellus patzcuarensis in Hungary: The first dwarf crayfish established outside of North America. Biologia 72: 1529-1532.

Weiperth A, Gál B, Kuříková P, Langrová I, Kouba A, Patoka J. 2019. Risk assessment of pet-traded decapod crustaceans in Hungary with evidences of Cherax quadricarinatus (von Martens) in the wild. North-Western J Zool 14: 42-47.

Weiperth A, Kouba A, Csányi B, Danyik T, Farkas A, Gál B, Józsa V, Patoka J, Juhász V, Pârvulescu L, Mozsár A, Seprős R, Staszny Á, Szajbert B, Ferincz Á. 2020. Az idegenhonos tízlábú rákok (Crustacea: Decapoda) helyzete Magyarországon [The present status of non-native Decapod (Crustacea: Decapoda) species in Hungary]. Halászat 113 61-69.

Yonvitner Y, Patoka J, Yuliana E, Bohatá L, Tricarico E, Karella T, Kouba A, Reynolds JD. 2020. Enigmatic hotspot of crayfish diversity at risk: Invasive potential of non-indigenous crayfish if introduced to New Guinea. Aquat Conserv 30: 219-224.

Zhang J, Kapli P, Pavlidis P, Stamatakis A. 2013. A general species delimitation method with applications to phylogenetic placements. Bioinformatics 29: 2869-2876.

Cite this article as: Weiperth A, Bláha M, Szajbert B, Seprős R, Bányai Z, Patoka J, Kouba A. 2020. Hungary: a European hotspot of nonnative crayfish biodiversity. Knowl. Manag. Aquat. Ecosyst., 421, 43. 